\title{
A Review of Fluoride Removal from Groundwater
}

\author{
Margandan Karunanithi ${ }^{1 *}$, Rachna Agarwal², Kushal Qanungo ${ }^{3}$ \\ ${ }^{1}$ Department of Chemistry, IFET College of Engineering, Villupuram, Tamilnadu, India \\ 2 Department of Chemistry, Mody University, Rajasthan, India \\ ${ }^{3}$ Department of Chemistry, Chandigarh University, NH-95, Gharuan, Mohali(Punjab), 140413, India \\ * Corresponding author, e-mail: margandan.123@gmail.com
}

Received: 12 February 2018, Accepted: 12 July 2018, Published online: 20 December 2018

\begin{abstract}
Most of the arid and semiarid zones of the Indian subcontinent are seriously affected by the fluorosis problem due to high concentration of the fluoride in ground water. Due to leaching of fluoride from the fluoride bearing rocks, the groundwater gets contaminated with fluoride. The different techniques for fluoride removal namely, the Activated alumina, the Nalgonda technique, bone charcoal, contact precipitation, electro-dialysis, reverse osmosis, ion-exchange, clay column, bio-adsorbents and MgO are discussed in detail. Their advantages and disadvantages together with the applicability in actual use also been discussed in the paper.
\end{abstract}

\section{Keywords}

fluoride, defluoridation, water purification

\section{Introduction}

High concentration of fluoride occurs naturally in ground water and causes fluorosis [1-3]. It is a serious health problem. The Bureau of Indian Standard (BIS) [4], this range is 0.6 from $1.2 \mathrm{ppm}$. Fluoride concentration from 0.6 to $1.5 \mathrm{ppm}$ in drinking water has been set by the World Health Organisation (WHO) [5]. This guideline value of fluoride is not universal and it varies from country to country. The Indian Standards Organization (ISO) suggests that the maximum permissible limit can be extended up to $1.5 \mathrm{ppm}$ [6]. Occurrence of fluoride bearing minerals and nature of the rocks determine the concentration of fluoride in ground water. Minerals like micas $\mathrm{X}_{2} \mathrm{Y}_{4}-6 \mathrm{Z}_{8} \mathrm{O}_{20}(\mathrm{OH}, \mathrm{F})_{4}$ where $\mathrm{X}=\mathrm{K}, \mathrm{Ca}, \mathrm{Na}, \mathrm{Y}=\mathrm{Al}, \mathrm{Mg}, \mathrm{Fe}$, $\mathrm{Z}=\mathrm{Si}, \mathrm{Al}$, fluorspar $\mathrm{CaF}_{2}$, fluorapatite $\mathrm{Ca}_{5}\left(\mathrm{PO}_{4}\right)_{3} \mathrm{~F}$, sellaite $\mathrm{MgF}_{2}$, biotite $\mathrm{K}(\mathrm{Mg}, \mathrm{Fe})_{3} \mathrm{AlSi}_{3} \mathrm{O}_{10}(\mathrm{OH}, \mathrm{F})_{2}$, cryolite $\mathrm{Na}_{3} \mathrm{AlF}_{6}$, topaz $\mathrm{Al}_{2} \mathrm{SiO}_{4}(\mathrm{OH}, \mathrm{F})_{2}$, muscovite $\mathrm{KAl}_{2}\left(\mathrm{AlSi}_{3} \mathrm{O}_{10}\right)(\mathrm{OH}, \mathrm{F})_{2}$, amphiboles such as tremolite $\mathrm{Ca}_{2} \mathrm{Mg}_{5} \mathrm{Si}_{8} \mathrm{O}_{22}(\mathrm{OH})_{2}$ [7-9] and hornblende $\mathrm{Ca}_{2}(\mathrm{Mg}, \mathrm{Fe}, \mathrm{Al})_{5}(\mathrm{Si}, \mathrm{Al})_{8} \mathrm{O}_{22}(\mathrm{OH})_{2}$ and villiaumite $\mathrm{NaF}$, contain high levels of fluoride. Due to leaching of fluoride from the fluoride bearing rocks, the groundwater gets contaminated with fluoride. Generally high alkalinity and low calcium favours high fluoride content in ground water [10]. In the tropical countries where water consumption is more because of the prevailing climate and there is fluoride bearing minerals underground, for example, Ethiopia, Tanzania, South Africa, Jordon, Egypt, Libya, Algeria, Sudan, Malawi, Mexico, Kenya, Pakistan, Brazil,
Afghanistan, Sri Lanka, Korea, Syria, Northern Thailand, Indonesia, and India many people are affected by fluorosis [11]. In many parts of Japan, Iran, Germany, China, Norway, Turkey, Southern Algeria, Italy, Canada and the United State of America, fluoride is also found above permissible limits [12]. In India, nearly 200 districts in 17 states with more than 6 million people are seriously affected by fluorosis and another 62 million are exposed to it [13]. Fluorosis is a wide spread problem, and more and more areas being discovered which are affected by fluorosis in several parts of the world. Many regions in southern and north western India are highly affected by fluorosis. The most fluoride affected states in India [14-16] are Andhra Pradesh, Tamil Nadu. Madhya Pradesh, Bihar, Haryana, Punjab, Uttar Pradesh, Gujarat, Maharashtra, Orissa, West Bengal and Rajasthan. All districts of Rajasthan a north-western state of India are affected by fluorosis. This is due to large deposits of fluoride containing minerals like fluorapatite, fluorspar and mica in Rajasthan [17-20]. The main source of ingestion of fluoride in our body is through drinking water.

\section{Fluoride Removal Methods}

\subsection{Bone Charcoal Method}

Bone charcoal has the ability to improve the colour, taste and odour of water. Most importantly, it can remove fluoride from water. The major components of bone charcoal 
are calcium phosphate $57-80 \%$, calcium carbonate $6-10 \%$, activated carbon 7-10\%. The fluoride removal process is mainly by the replacement of the hydroxide groups of hydroxyapatite by fluoride [4,7].

$\mathrm{Ca}_{10}\left(\mathrm{PO}_{4}\right)_{6}(\mathrm{OH})_{2}+2 \mathrm{~F}^{-} \rightarrow \mathrm{Ca}_{10}\left(\mathrm{PO}_{4}\right) 6 \mathrm{~F}_{2}+2 \mathrm{OH}^{-}$.

High fluoride sorption capacity, local availability and cheapness of animal's bones are some of the advantages of using bone char. Also no chemicals are added during the defluoridation process. However, there is limited acceptability of animal's bones as filter materials for drinking water due to religious beliefs. High initial investments and experience needed to set up bone char production, maintenance and regular monitoring of the filter are some of the impediments for this technique to become popular. If the bone charcoal is saturated it needs to be regenerated or replaced. Defluoridation of water using bone charcoal has studied by Larsen et al. [21]. The dissolution pattern of bone charcoal used for defluoridation and crystalline carbon content and have been studied. The defluoridation of water using bone char column at various inlet fluoride concentration and flow rate has been studied by Mwaniki et al. [22]. $\mathrm{CaCl}_{2}$ and $\mathrm{NaHSO}_{4}$ at $\mathrm{pH} 3.0$ have been used Christoffersen et al. [23] to regenerate a bone charcoal column used for defluoridation. The defluoridation of drinking water using fluorapatite precipitation technique has been studied by Larsen and Pearce [24].

\subsection{Contact Precipitation}

Addition of calcium and phosphate compounds and then bringing the water in contact with saturated bone charcoal medium.

Dissolution of calcium chloride

$\mathrm{CaCl}_{2} \cdot 2 \mathrm{H}_{2} \mathrm{O}(\mathrm{s}) \rightarrow \mathrm{Ca}^{+}+2 \mathrm{Cl}^{-}+2 \mathrm{H}_{2} \mathrm{O}$

Precipitation of calcium fluoride

$\mathrm{Ca}^{+}+2 \mathrm{~F}^{-} \rightarrow \mathrm{CaF}(\mathrm{s})$

Precipitation of calcium fluorapatite

$10 \mathrm{Ca}^{+}+6 \mathrm{PO}^{-}+2 \mathrm{~F}^{-} \rightarrow \mathrm{Ca}(\mathrm{PO}) 6 \mathrm{~F}(\mathrm{~s})$.

In this process fluoride is removed from the water by the addition of phosphate and calcium compounds in contact with a saturated bone charcoal medium. As compared to bone charcoal method, fluoride uptake capacity and life of the filter using contact precipitation is significantly higher. However, the chemical processes of fluoride removal by contact precipitation are not yet fully understood, the calcium phosphate pellets cannot be regenerated and the process is time consuming. The contact precipitation as a viable water defluoridation technique has been studied by Okello [25]. Using column experiments, the defluoridation capacity of bone charcoal and plan Minjigu rock has been determined. The defluoridation technique using contact precipitation has been described by Dahi [26]. In this process, the bone char is placed in contact with fluoride contaminated water mixed with $\mathrm{CaCl}_{2}, \mathrm{Ca}_{3}\left(\mathrm{PO}_{4}\right)_{2}$. Jar test, column setup, filter contact column experiments and a pilot defluoridation plant has been set up in this study.

\subsection{The Nalgonda Technique}

This method used at both community and household levels was originally developed by the National Environmental Engineering Research Institute, Nagpur in India. Lime and aluminium sulphate are added in calculated quantities in the process. Lime aids in forming dense flocks for rapid settling of insoluble fluoride salts. The choice of either $\mathrm{Al}_{2}\left(\mathrm{SO}_{4}\right)_{3}$ or $\mathrm{AlCl}_{3}$ depends on $\mathrm{SO}^{2-}$ and $\mathrm{Cl}^{-}$conc. of raw water. As rule of thumb, the dose of lime is $1 / 20$ th of that of dose of aluminium salt. Coagulation / flocculation and sedimentation removes the fluoride. The addition of lime helps to form dense flocs which settle rapidly and help to remove the fluoride. Also, a $\mathrm{pH}$ of around 6-7 is achieved at which aluminium is completely removed. For disinfection bleaching powder is added to the raw water [4, 7]. The reactions involved in this process are:

$$
\begin{aligned}
& 6 \mathrm{Ca}(\mathrm{OH})_{2}+12 \mathrm{H}^{+} \rightarrow 6 \mathrm{Ca}^{+}+18 \mathrm{H}_{2} \mathrm{O} \\
& \mathrm{Al}_{2}\left(\mathrm{SO}_{4}\right)_{3} .18 \mathrm{H}_{2} \mathrm{O} \rightarrow 2 \mathrm{Al}^{3+}+3 \mathrm{SO}^{2-}+18 \mathrm{H}_{2} \mathrm{O} \\
& 2 \mathrm{Al}^{2+}+6 \mathrm{H}_{2} \mathrm{O} \rightarrow 2 \mathrm{Al}(\mathrm{OH})_{3}+6 \mathrm{H}^{+}
\end{aligned}
$$

$\mathrm{F}^{-}+2 \mathrm{Al}(\mathrm{OH})_{3} \rightarrow \mathrm{Al}-\mathrm{F}$ complex + undefined product.

The Nalgonda technique is a work-intensive method due to the need of daily mixing of alum and lime. The fluoride elimination rate is however, low (70-80\%). Also there is a risk of contamination of the treated water by aluminium in case of overdosing of aluminium sulphate. This is partly due to the very low permissible limit of aluminium according to WHO (0.2 ppm). The fluoride removal processes by the Nalgonda technique are well understood. The chemicals used in the process are cheap and locally available, and the treatment is well accepted by locals. We review briefly a few papers using the Nalgonda technique for fluoride removal. Lime, bleaching powder and 
alum have been used by Nawlakhe et al. [27] the defluoridation process. For the various concentrations of fluoride in ground water the dosages of the chemical have been optimized. Cost calculations have also been carried out for the process. Dahi et al. [28] has studied the Nalgonda technique of defluoridation in Tanzania. They report that the local households operated the filter themselves and are willing to modified by Suneetha et al. [29] by doubling the concentration of alum and lime. The decrease in fluoride levels in water treated by this method was more than the original Nalgonda technique. Projects of domestic defluoridation were carried out in Rajasthan and Andhra Pradesh. The defluoridation studies conducted at IIT Kanpur from 1991 to 2005 have been summarized by Iyenger [35]. Two different models of hand pump based defluoridation units have been developed by the Public Health Engineering Department (PHED) Rajasthan in collaboration with the DST Rajasthan. Domestic Defluoridation Unit (DDU) using indigenously manufactured AA with particle size ranging from 0.4 to $1.2 \mathrm{~mm}$ has been studied by Chauhan et al. [36]. By regenerating the AA, the reuse potential of exhausted AA was also studied. The fluorosis mitigation programme in Dungarpur district of Rajasthan using the Nalgonda technique and AA based filters have been discussed by Vaish and Vaish [37]. Due to the problem of daily disposal of sludge, this technique is not preferable. Draft standards have been prepared for the use of AA suitable for use in the DDU's [38]. A fluoride filter based on AA called FLOWAT has been developed and field tested by Dzung et al. [39].

\subsection{Activated Alumina (AA)}

AA surface is amphoteric in nature and can exist as $\mathrm{AlOH}^{+}$, $\mathrm{AlOH}$ and $\mathrm{AlO}^{-}$. Fluoride binding to $\mathrm{AA}$ is proposed to be due to exchange of surface hydroxyl groups, which can be represented by the following reaction.

$$
\mathrm{AlOH}_{2}+\mathrm{F} \rightarrow \mathrm{AlF}+\mathrm{H}_{2} \mathrm{O}
$$

$$
\mathrm{AlOH}+\mathrm{F}^{-} \rightarrow \mathrm{AlF}+\mathrm{OH}^{-} .
$$

Activated alumina is a good adsorbent due to its small size, and large surface area. The fluoride removal ability of AA depends on the grade of AA, particle size and the $\mathrm{pH}$, alkalinity and fluoride concentration in water.

The AA technique requires minimum contact time with fluoride contaminated water for defluoridation. The exhausted AA can be easily regenerated. AA is available indigenously and quite cheap. Adsorption efficiency of the AA gets lowered with increasing number of regeneration cycles. The defluoridation capacity of AA is maximum at $\mathrm{pH}$ 5-7. AA is easy also to relatively handle.

The activated alumina is needed to be replaced very frequently which make the technique expansive. Regeneration generates fluoride rich solution, causing disposal problem. Defluoridation filters with AA can be fabricated easily and the filter requires no electricity and no maintenance. The presence of $\mathrm{HCO}^{-}$ions, however reduces the fluoride removal ability of AA47. A term paper on removal of fluoride from water using AA has been submitted by Stewart [30]. Karthikeyan et al. [31] have studied the fluoride removal from water using AA and its regeneration using dil. $\mathrm{HCl}, \mathrm{NaOH}$ and $\mathrm{H}_{2} \mathrm{SO}_{4}$. The kinetics of fluoride removal using AA prepared from pseudo-boehmite has been studied by Leyva-Ramos et al. [32].

\subsection{Activated Alumina Based Domestic Defluoridation Units}

The development of DDU's for use in rural in India have been discussed by Venkobacher et al. [33]. Different grades of AA have been used in the DDU's and their fluoride removal ability determined. The experience of UNICEF in tackling the problem of fluorosis in rural areas using DDU's containing AA have been summarised by Daw [34]. The UNICEF had supported the development technology for the AA filters at IIT Kanpur since 1991. During the period 1996-2002, pilot.

\subsection{Clay}

Essentially clay is finely powdered rock composed of hydrous aluminium silicate and other minerals and impurities. Clay powder and fired clay are both capable of adsorption of fluoride from water. If clay is locally available then fluoride removal using clay is very low cost. However, the fluoride adsorption capacity of clay is low, and the fluoride removal is time consuming. We now review a few important papers using the clay for fluoride removal [4, 7]. Padmasiri in Sri Lanka has used brick pieces for making defluoridation filters [40]. PVC pipe or cement bricks make the outer body of the filter. The efficiency at the start of the operation of fluoride filter was found to be $85 \%$ and becomes $25 \%$ at the end of the process. The brick pieces have to be replaced when saturation of the brick pieces was reached (between 90 and 250 days). The use of soil as a defluoridating material for drinking water has been studied by Wang and Reardon [41]. They have found that heavily weathered tertiary soil from Xinzhou, China is an F-specific sorbent. A permeable granular material which is suitable for column use can 
be generated by heat treatment of soil. Using iron oxyhydroxyoxide the soil can be regenerated. Kaolinite clay for defluoridation purpose has been used by Jinadasa et al. [42]. Fluoride adsorption and desorption reactions in the clay have been investigated. The fluoride adsorption conforms to both Langmuir and Freundlich isotherms, while the fluoride desorption conform only to the Freundlich isotherm. Gupta et al. [43] have studied the defluoridation of water using raw bentonite. Kinetic studies have been performed using bentonite of different mesh size.

The fluoride adsorption characteristics of clay collected from different regions of Ethiopia for fluoride removal have been studied by Tikariha and Sahu [44]. The effects of amount of adsorbent dose, $\mathrm{pH}$, particle size, contact time, and heat treatment of clays have been studied. The defluoridation ability of natural red soil have been studied by Chidambaram et al. [45]. Their findings indicate that the $\mathrm{FeOH}, \mathrm{AlOH}$ bonds present in soil play the main role in contributing to the efficiency of fluoride removal.

Selected South African clays for fluoride removal from ground water have been used by Coetzee et al. [46]. Chemically activation of clays using $1 \% \mathrm{NaHSO}_{4}$ solution and dilute $\mathrm{HCl}$ enhance fluoride adsorption. Locally available material like laterite, sand and gravel for fluoride removal from water have been used Jayantha et al. [47]. Chemically modified bentonite clay has been used for the defluoridation of drinking water by Kamble et al. [48]. The bentonite clay was chemically modified by lanthanum, magnesium and manganese. Acidic $\mathrm{pH}$ favoured more uptake of fluoride as compared to alkaline $\mathrm{pH}$. The Langmuir and Freundlich isotherm models were used to fit the equilibrium adsorption data. The fluoride removal was affected by the presence of both $\mathrm{CO}^{2-}$ and $\mathrm{HCO}^{-}$.

The adsorption mechanism of fluoride by clays has been studied Puka [49]. Their research indicates that principle mechanism for the fluoride removal was by the exchange of hydroxyl ions by fluoride ions in the clay structure. The adsorption capacity of clay was enhanced by coating the clay samples with aluminium and iron oxides. Aluminium oxalate has been used as an adsorbent by Yadav et al. [50] for preparing traditional soil pots to remove fluoride from drinking water.

\subsection{Reverse Osmosis}

In Reverse Osmosis (RO) water is forced under pressure through a semi-permeable membrane, thereby removing dissolved solutes from solution. This process can remove $85-95 \%$ of fluoride from water. The RO is the best technique for removing both fluoride and arsenic, however it has high water wastage of 20-40 \%, high energy consumption and high capital costs. In most cases pre-filtration and post-pH / alkalinity adjustment the treatment may be needed. For cleaning of the RO membrane, chemical handling facilities and a skilled operator is needed $[4,7]$. Schneiter and Middlebrooks [51] have used reverse osmosis to remove fluoride and arsenic from groundwater while arsenic was reduced by $60-90 \%$, fluoride conc. was reduced by $60 \%$. Richards et al. have used a two stage membrane process with ultrafiltration followed by nanofiltration / reverse osmosis to remove fluoride and arsenic from groundwater in central Australia [52]. Dolar et al. have studied the use of reverse osmosis in removing fluoride and phosphate from efficiently from fertilizer industries [53]. Schoeman et al. have used reverse osmosis to treat effluent from stainless steel factory. Fluoride among other ions would be effectively removed [54].

RO has been used by Min et al. for fluoride removal [55]. In the recent years increased demands and contamination of water and simultaneous stringency in water quality parameters standards and the problem associated with other methods have led to the development of membrane technology for water purification. Efficiency of the RO process is governed by different factors such as characteristic of raw water, temperature, pressure and requires regular monitoring and maintenance etc. The reject water from the RO process has been treated using $\mathrm{CaCO}_{3}$ by Babu et al. [56].

\subsection{Electro Dialysis (ED)}

In Electro-Dialysis (ED) an applied D. C. current, instead of pressure is used to separate ionic contaminants from water. Thus ED membranes are not technically considered as filters as water does not physically pass through the membrane in the ED process. Also particulate matter is not removed. The ED process can remove $85-95 \%$ fluoride from water $[4,7]$.

The ED method relies heavily on our present technical familiarity with the membrane based separation systems. However, it is very costly, there is significant water loss in form of brine discharge, high energy consumption and high capital costs. There may be a requirement of pre-filtration and post-pH / alkalinity adjustment. For the membrane maintenance, chemical handling facilities and skilled operators are required. On the basis of industrial and economic data, Lahnid et al. have conducted an economic evaluation of fluoride removal by electro-dialysis [57]. The performance of electro-dialysis and nano-filtration in fluoride 
removal from Moroccan ground water has been compared by Elazhar et al. [58]. The fluoride reduction and performance of two technologies have been found to be comparable. Electro-dialysis in continuous operation mode for fluoride removal from Moroccan ground water has been used Tahaikt et al. [59]. Under various experimental conditions and optimization study of the electro dialysis operation was carried out. To determine the optimum operating conditions the water quality parameters as well as power consumption and recovery rate were closely monitored.

The fluoride removal from polluted water using electro-dialysis has been studied Ali et al. [60]. The fluoride removal rate, demineralization rate and power consumption have been optimised.

Kabay et al. have studied the effect of process parameters and other ionic species on fluoride removal by electro-dialysis [61]. The separation performance has been evaluated in terms of mass transfer and energy consumption. The defluoridation using the electro-dialysis technique has been studied Amor et al. [62]. Their results show that with increase in operating voltage and temperature, defluoridation and desalination rates increases. Amor et al. have used electro-dialysis for fluoride removal from brackish water with a TDS of $3000 \mathrm{ppm}$ and fluoride concentration [63] of 3 ppm. The defluoridation of water during the desalination of brackish water by electro-dialysis has been studied Adhikary et al. [64]. Zeni et al. have studied the fluoride reduction using electro dialysis from artesian well water [65].

The optimum operational conditions of the electro-dialysis cell have been determined for treating brackish water of 5000 ppm TDS and 15 ppm F$^{-}$and obtaining water with less than 600 ppm. Menkouchi Sahli et al. have studied the fluoride removal using electro-dialysis and natural chitosan [66]. CMX-ACS membranes have been used for electro dialysis. The results show that coupling of these two processes is an interesting alternative to remove fluoride from brackish water with high fluoride content. Banasiak and Schäfer have studied the removal of boron, fluoride and nitrate by electro-dialysis in the presence of organic matter [67]. Deposition of organic matter on the separation membranes occurred during the process.

\subsection{Bio-adsorbents}

Bio-adsorbents prepared from dry fruits collected from plants Enterolobium saman (ESC), Acasia arabic (AAC), Prosopis juliflora (PLC) have been used by Maheshwari et al. for defluoridation purposes. The fluoride removal ability has been compared with granular activated carbon [68].
The equilibrium contact time for fluoride removal and the optimum dose of adsorbent has been determined. Tea ash as a bio-sorbent for fluoride removal has been used by Mondal et al. [69]. The defluoridation capacity decreases with initial concentration of fluoride solution but increases with increasing adsorbent dose and contact time. $\mathrm{Na}_{2} \mathrm{CO}_{3}$ modified bagas and chitosan have been used by Ardekani et al. for fluoride removal [70]. At an adsorbent dose of $2 \mathrm{~g} /$ lit, the fluoride adsorption is maximum at $\mathrm{pH} 7$ and reaches equilibrium in 60 min time. Rare earth modified chitosan for defluoridation purposes have been used by Liang et al. [71]. The effect of various parameters such as initial fluoride concentration contact time, effect of co-ions and adsorbent dose have been studied. The adsorption of fluoride by this material was greatly influenced by the presence of $\mathrm{HCO}^{-}$ and $\mathrm{CO}^{2-}$ ions. The rice husk and seed extract of Moringa oleifera (drum stick), modified by $\mathrm{MnCl}_{2}$ and $\mathrm{MnSO}_{4}$ have been studied by Vardhan and Karthikeyan [72]. The adsorption of fluoride with respect to variation of initial fluoride concentration, adsorbent dose, heat treatment presence of interfering ions and $\mathrm{pH}$ were investigated. A bio-adsorbent made from Phyllantus albicato remove fluoride from water have been used by Veeraputhiran and Alagumuthu [73]. Higher adsorption of fluoride is achieved with smaller particle size and increasing dose of adsorbent increases the fluoride adsorption capacity. The interference of co-ions on fluoride removal was found to be in the following order $\mathrm{HCO}^{-}>\mathrm{SO}^{2-}>\mathrm{Cl}^{-}>\mathrm{NO}^{3-}$.

\subsection{Ion Exchange}

In the ion exchange process, water is allowed to flow down through a column packed with an ion exchange resin. When the resin becomes saturated, the filter material has to be regenerated with a mild acid / alkali solution.

Matrix- $\mathrm{NR}_{3}+\mathrm{Cl}^{-}+\mathrm{F}^{-} \rightarrow$ Matrix- $\mathrm{NR}_{3}+\mathrm{F}^{-}+\mathrm{Cl}^{-}$.

To avoid recontamination of nearby ground water the effluent from backwashing rich in accumulated fluoride, must be therefore disposed of properly [4, 7]. The ion exchange method is simple to operate, does not require any electricity and also makes hard water soft. However, it is initial capital cost is high. The defluoridation of drinking water using Al doped Amino-methylene-phosphine-acid resigns called Lewatit Mono Plus TP 260 has been studied by Oke et al. [74]. Ho et al. have studied fluoride removal by ion exchange using mesoporous Titanium hydroxide containing zirconia [75]. Pilot plant studies using this technique indicate the suitability of this process under weakly 
acidic conditions $(\mathrm{pH}=4)$. The selective removal of fluoride by ion exchanger HP-555 followed by another ion exchanger column (IR-458) has been studied by Castel et al. [76]. The fluoride removal from a carbonated water containing $\mathrm{Cl}^{-}$and $\mathrm{SO}^{2-}$ as major ions can be successfully achieved using this patented process. A cost effective and dual functional muslin-based anion exchangers that can function both as a defluoridating agent and antimicrobial antifungal agent have been designed by Kumar et al. [77]. The experimental data fitted into Langmuir adsorption isotherm and follows a pseudo second order kinetics. Ruixia et al. have studied the fluoride removal using a new type of ion exchange fibre [78]. Fluoride, phosphate and arsenate ions can remove by this method. The adsorption data fitted well with the Freundlich isotherm model and a pseudo second order kinetics is followed. Singh et al. have studied the removal of fluoride from spent pot liner leachates using an ion exchange [79]. The spent pot liner leachates were pretreated with lime to bring down the fluoride level to $10 \mathrm{ppm}$ for economic and effective working of the ion exchanger.

\subsection{1 $\mathrm{MgO}, \mathrm{CaO}, \mathrm{CaCl}_{2}$ and $\mathrm{NaHSO}_{4}$ Technique (IISc Method)}

Principle of the Method

$\mathrm{MgO}+\mathrm{H}_{2} \mathrm{O} \rightarrow \mathrm{Mg}(\mathrm{OH})_{2}$.

$\mathrm{F}^{-}$in Water gets trapped into the $\mathrm{Mg}(\mathrm{OH})_{2}$ precipitate as settles down. Water becomes alkaline between $\mathrm{pH} 10.1$ to 10.3 on addition of $\mathrm{MgO}$.

$\mathrm{NaHSO}_{4}$ is used to reduce the $\mathrm{pH}$ of $\mathrm{MgO}$ treated Water to Within Potable Water limits (6.5 to 8.5)

$$
\begin{aligned}
& \mathrm{HSO}^{-}+\mathrm{OH}^{-} \rightarrow \mathrm{SO}^{2-}+\mathrm{H}_{2} \mathrm{O} \\
& \mathrm{HCO}^{-}+\mathrm{OH}^{-} \rightarrow \mathrm{CO}^{2-}+\mathrm{H}_{2} \mathrm{O}
\end{aligned}
$$

additional $\mathrm{NaHSO}_{4}$ is consumed

$$
\mathrm{CO}^{2-}+\mathrm{HSO}^{-} \rightarrow \mathrm{HCO}^{-}+\mathrm{SO}^{2-} \text {. }
$$

$\mathrm{Ca}(\mathrm{OH})_{2}$ is added to convert soluble bicarbonates to insoluble $\mathrm{CaCO}_{3}$ as

$\mathrm{HCO}^{-}+\mathrm{Ca}^{2+}+\mathrm{OH}^{-} \rightarrow \mathrm{CaCO}_{3}+\mathrm{H}_{2} \mathrm{O}$.

$\mathrm{CaCl}_{2}$ is added to increase conc. of $\mathrm{Ca}^{2+}$ in water.

A new method of defluoridation using $\mathrm{MgO}, \mathrm{CaO}$, $\mathrm{CaCl}_{2}$, and $\mathrm{NaHSO}_{4}$ has been developed by Rao and Pemmaraju [80]. The defluoridation filter consistent of two chambers, in the top chamber calculated doses of $\mathrm{MgO}, \mathrm{CaO}$ and an aqueous solution of $\mathrm{CaCl}_{2}$ are added to fluoride contaminated ground water and stirred well either using a mechanical or a handheld stirrer. The solution is left undisturbed for 16 hours for the flocs to settle down. The clear supernatant water is transfer to the bottom container using a flexible tube fitted at the bottom of the top container [81]. The $\mathrm{pH}$ adjustment is done using $\mathrm{NaHSO}_{4}$ in the bottom container. Using a tap, the potable water can be drawn off from the bottom container [82]. In a further development of this method, Pemmaraju and Rao have used a two stage filter unit with an electric stirrer and layers of cotton cloth to filter out any sludge particles before the $\mathrm{pH}$ adjustment step [83, 84]. For waters containing different bicarbonate concentrations and fluoride levels the various doses of $\mathrm{MgO}, \mathrm{CaO}, \mathrm{CaCl}_{2}$ and $\mathrm{NaHSO}_{4}$ for $\mathrm{pH}$ adjustment are also given [85]. For environmentally safe disposal of the fluoride containing sludge and its conversion into building materials [86], the sludge has been incorporated into stabilized mud blocks.

\subsection{2 $\mathrm{MgO}, \mathrm{CaO}, \mathrm{CaCl}_{2}$ and $\mathrm{HCL}$ techniques Implemented}

The village of Pilaniyon Ki Dhani a sub-village of Shola in Lakshmangarh Tehsil of Sikar District of Rajasthan is a small hamlet of six homes with a population of 120 people. It is a remote village with harsh climate conditions, low rainfall and rain fed agriculture as the main occupation.

It is connected to the main village of Shola, one $\mathrm{km}$ away by a gravel road. The nearest village is Jajod, located eight $\mathrm{km}$ away. There is two tube wells (called Manish T.W. and Sungaram T.W.), in this village which supply water to all homes. Most of the people in the village of Pilaniyon Ki Dhani show typical symptoms of fluorosis, e.g. pain in legs, back pain, early signs of aging etc. Our initial studies had indicated that the water of the Manish T.W. had high levels of fluoride $>10 \mathrm{ppm}$ together with high $\mathrm{HCO}^{-}$conc. $\approx 1561 \mathrm{ppm}$.

This village of Pilaniyon Ki Dhani [87] was chosen as a part of a Water Technology Initiative, Dept. of Science and Technology, Govt. of India, project to conduct field trials of a filter using $\mathrm{MgO}, \mathrm{CaO}, \mathrm{CaCl}_{2}$ and $\mathrm{HCl}$ recently developed at IISc Bangalore. The choice of this village was due to its fluorosis problem, its relative proximity to the Institute, $(26 \mathrm{~km})$, and the initial interest shown by the local villagers towards the defluoridation filter.

\section{Fluoride Health Effects}

The degree of dental fluorosis depends on the amount of fluoride exposure up to the age of 8-10, as fluoride stains 
only the developing teeth while they are being formed in the jawbones and are still under the gums. The effect of dental fluorosis may not be apparent if the teeth are already fully grown prior to the fluoride over exposure. Therefore, the fact that an adult shows no signs of dental fluorosis does not necessarily mean that his or her fluoride intake is within the safety limit [88].

Skeletal fluorosis was also found in children with low prevalence $(5.2 \%)$ [89] but at high $\mathrm{F}$ concentration (4.8 ppm). The prevalence of skeletal fluorosis was relatively higher in males and increased with higher $\mathrm{F}$ level and age. Deformities such as crippling, kyphosis, invalidism and genu-varum were observed frequently in higher age group subjects (gt; 48 years) at F concentration of $3.3 \mathrm{ppm}$. None of fluorotic individuals revealed evidence of genu-valgum syndrome and goitre (thyroidism). Radiological findings of other deformities in fluorotic subjects were also found. The distribution of $\mathrm{F}$ and endemic fluorosis in different districts of Rajasthan state have also been reviewed [90].

The adult residents of these villages use drinking water high in fluoride content which may be the primary cause of dental fluorosis. During examination of the teeth of adult residents of these areas, it was observed that $61.06 \%$ of the residents of the high fluoride and $48.32 \%$ areas were suffering from dental fluorosis. Risk of dental fluorosis was significantly higher in the areas showing more fluoride content in drinking water. Defluoridation of drinking water is the only remedy to save the local population from dental fluorosis [91].

Depending upon amount of the fluoride in drinking water, fluoride may be beneficial or harmful for human health. For the development of the enamel of teeth a certain amount of fluoride is essential. The size of the apatite crystals in the skeletal system is increased due to fluoride. Fluoride incorporation into the skeletal system and dental enamel is dependent on age $[92,93]$. When the fluoride concentration in drinking water is more than $2 \mathrm{ppm}$, dental fluorosis begins. Tooth enamel is mainly made up of hydroxyapatite which is crystalline calcium phosphate. $\mathrm{F}^{-}$displaces the $\mathrm{OH}^{-}$from hydroxyapatite to form fluoroapatite [94]. Fluorosis of dental enamel occurs when excess fluoride is ingested during the early years of tooth calcification particularly during the first 7 years of life. The formations of yellow glistening patches on the teeth are the symptoms of early stage of dental fluorosis. In the final stages, the yellow-brown patches may turn black and affect the whole tooth. Matrimonial issues [95] are one serious social aspect of dental fluorosis.
Drinking water containing more than 3-6 ppm of fluoride for long periods causes skeletal fluorosis. Young and old alike are affected by skeletal fluorosis. If the mother consumes water and food, with a high concentration of fluoride during pregnancy / breast feeding, fluoride can also damage the foetus. Calcification of blood vessels can cause infant mortality. Severe pain in the backbone, joints, hip region, stiffness of the backbone, immobile / stiff joints, increased density of bones, besides calcification of ligaments, constriction of vertebral canal and inter-vertebral foramen-pressure on nerves and paralysis [96, 97] are some symptoms of skeletal fluorosis. Nervousness, stiffness, tingling sensation in fingers and toes, muscle weakness, excessive thirst, tendency to urinate frequently, pain in the muscle and loss of muscle power are some of the non-skeletal manifestations of fluorosis. Ingestion of fluoride over prolonged periods can also lead to change in the DNA structure [98, 99]. Painful, round shaped pinkish, reddish or bluish spots on the skin are some of the allergic manifestations. Acute abdominal pain, blood in stools, feeling of nausea bloated feeling, diarrhoea; constipation and tenderness in stomach are some of the gastrointestinal symptoms of fluorosis.

It is essential to bring reduce fluoride concentration in ground water for developmental purpose.

\section{Conclusion}

A brief review has been attempted to cover a verity of adsorbent which has been fluoride removal from fluoride contaminated water. The fluoride removal methods have been broadly separate into two types with membrane and adsorption techniques. Reverse osmosis, Electro dialysis, ion exchange has been discussed under membrane techniques. Adsorption methods such as, Activated alumina and Nalgonda technique, Bone charcoal, Bio-Adsorbents, $\mathrm{MgO}, \mathrm{CaO}, \mathrm{CaCl}_{2}$, and $\mathrm{HCl}$ (IISC Method). Due to leaching of fluoride bearing rocks have been found fluoride content in ground water varying from 0.1 to $12.0 \mathrm{ppm}$. In similar way fluoride bearing water was reported by many parts of world and India such as Rajasthan, A.P, Punjab, Haryana, Tamilnadu, Karnataka, Madhya Pradesh, and Gujarat. Fluoride is known for both beneficial and harmful effect on health. Fluoride in drinking water has an intense effect on bone and teeth. In low level between $1-1.5 \mathrm{mg} / 1$ it improves the enamel. Fluoride concentration in the range of $1.5-4 \mathrm{mg} / 1$ results in dental fluorosis, whereas at high concentrations $4-10 \mathrm{mg} / \mathrm{l}$ causes skeletal fluorosis (Table 1). Fluorosis Disease caused by intake of 
Table 1 Comparison between the fluoride removal methods

\begin{tabular}{|c|c|c|c|c|c|}
\hline $\begin{array}{l}\text { Name of the } \\
\text { methods }\end{array}$ & Process & Removal Performance & Cost & Advantages & Disadvantages \\
\hline $\begin{array}{l}\text { Bone charcoal } \\
\text { Method }\end{array}$ & Adsorption & $\begin{array}{l}\text { Fluoride concentration } \\
\text { can be reduced to less } \\
\text { than or equal to } 1 \mathrm{mg} / 1\end{array}$ & Low & $\begin{array}{l}\text { Locally available, simple and } \\
\text { easy to build }\end{array}$ & $\begin{array}{l}\text { May give bad taste; degenerates, } \\
\text { Not universally accepted }\end{array}$ \\
\hline $\begin{array}{l}\text { Contact } \\
\text { precipitation }\end{array}$ & Precipitation & $>90 \%$ removal of $\mathrm{F}$ & Low & $\begin{array}{l}\text { High reliability without the } \\
\text { need of surveillance of flow } \\
\text { efficiency }\end{array}$ & $\begin{array}{l}\text { The filter using contact } \\
\text { precipitation is significantly } \\
\text { higher }\end{array}$ \\
\hline $\begin{array}{l}\text { The Nalgonda } \\
\text { Technique }\end{array}$ & $\begin{array}{l}\text { Aluminium } \\
\text { sulphate based } \\
\text { coagulation- } \\
\text { flocculation } \\
\text { sedimentation }\end{array}$ & $\begin{array}{l}\text { The method does not } \\
\text { permit Low sufficient } \\
\text { removal of the fluoride, } \\
\text { even when appropriate } \\
\text { dosage is used. }\end{array}$ & Low & $\begin{array}{l}\text { Understanding of the } \\
\text { nonstoichiometric } \\
\text { co-precipitation mechanisms } \\
\text { for removal of fluoride in the } \\
\text { flocculation process. }\end{array}$ & $\begin{array}{l}\text { The treatment efficiency is limited } \\
\text { to about } 70 \% \text {. Thus the process } \\
\text { would be less satisfactory in } \\
\text { case of medium to high fluoride } \\
\text { contamination in the raw water. }\end{array}$ \\
\hline $\begin{array}{l}\text { Activated Alumina } \\
\text { (AA) }\end{array}$ & Adsorption & $\begin{array}{l}\text { According to WHO the } \\
\text { fluoride removal capacity } \\
\text { of alumina is between } 4 \\
\text { and } 15 \mathrm{mg} \text { - } 1 \text {. Experience } \\
\text { from the field }\end{array}$ & High & $\begin{array}{l}\text { Effectiveness, will treat } \\
\text { current } \mathrm{F} \text { and } \mathrm{S}\end{array}$ & $\begin{array}{l}\text { Spent regeneration solution } \\
\text { contains high F concentration }\end{array}$ \\
\hline $\begin{array}{l}\text { Activated alumina } \\
\text { based domestic } \\
\text { defluoridation units }\end{array}$ & Adsorption & $\begin{array}{l}\text { The efficiency at the start } \\
\text { of the operation of fluoride } \\
\text { filter was found to be } 85 \% \\
\text { and becomes } 25 \% \text { at the } \\
\text { end of the process }\end{array}$ & Low & Locally available & $\begin{array}{l}\text { Low capacity, slow, low removal } \\
\text { efficiency }\end{array}$ \\
\hline Reverse Osmosis & $\begin{array}{l}\text { Membrane } \\
\text { Technology }\end{array}$ & $\begin{array}{c}85-95 \% \text { removal of } \mathrm{F} \\
\text { Scale }\end{array}$ & $\begin{array}{l}\text { Very } \\
\text { high }\end{array}$ & $\begin{array}{l}\text { Familiarity with membrane } \\
\text { separation system }\end{array}$ & $\begin{array}{l}\text { High water loss }(20-40 \%) \\
\text { due to high source water silica } \\
\text { concentrations (for RO). }\end{array}$ \\
\hline $\begin{array}{l}\text { Electro-Dialysis } \\
\text { (ED) }\end{array}$ & $\begin{array}{l}\text { Membrane } \\
\text { Process }\end{array}$ & $\begin{array}{l}\text { performance: } 85-95 \% \\
\text { removal of F Scale }\end{array}$ & $\begin{array}{l}\text { Very } \\
\text { high }\end{array}$ & Familiarity with membrane & High energy consumption \\
\hline Bio-Adsorbents & Adsorption & Depends on the size & Low & $\begin{array}{l}\text { Smaller particle size and } \\
\text { increasing dose of adsorbent } \\
\text { increases the fluoride } \\
\text { adsorption capacity }\end{array}$ & $\begin{array}{l}\text { The interference of co-ions on } \\
\text { fluoride removal was found to be } \\
\text { in the following order } \\
\mathrm{HCO}^{3-}>\mathrm{SO}_{4}{ }^{2-}>\mathrm{Cl}^{-}>\mathrm{NO}_{3} \text {. }\end{array}$ \\
\hline Ion exchange & Ion exchange & $\begin{array}{l}\text { Medium-high; Depends } \\
\text { on quality of water }\end{array}$ & High & $\begin{array}{l}\text { The fluoride removal from a } \\
\text { carbonated water containing } \\
\mathrm{Cl}^{-} \text {and } \mathrm{SO}_{4}^{2-} \text { as major ions } \\
\text { can be successfully achieved }\end{array}$ & $\begin{array}{l}\text { High costs, low capacity, } \\
\text { sorption of other anions, Fluoride } \\
\text { concentration must be less than } \\
10 \mathrm{mg} / \mathrm{l} \text {. }\end{array}$ \\
\hline $\begin{array}{l}\mathrm{MgO}, \mathrm{CaO}, \mathrm{CaCl}_{2} \\
\text { and } \mathrm{HCl} \text { Technique } \\
\text { (IISc Method) }\end{array}$ & Adsorption & High & Low & Environmental safe disposal & - \\
\hline
\end{tabular}

Table 2 Fluoride concentration and its effects.

\begin{tabular}{lc}
\hline Fluoride $(\mathrm{mg} / \mathrm{L})$ & Concentration Effects \\
\hline$<0.5$ & Conducive to dental caries. \\
$0.5-1.5$ & Promotes development of strong bones and teeth. \\
$1.5-4.0$ & Promotes dental fluorosis in children. \\
$>4$ & Promotes dental and skeletal fluorosis. \\
$>10$ & Crippling skeletal fluorosis, possibly cancer. \\
\hline
\end{tabular}

fluoride in excess through food, water and air is serious health problem. Fluoride ingested with water accumulated in bones up to age above 60 years. Depending upon the amount of fluoride ingested illness varying degree of skeletal, dental and non-skeletal fluorosis. A number of methods of defluoridation techniques available for removal of fluoride, although not all the methods are suitable for all circumstance and hence proper justification required for appropriate method to implement. Certain method like $\mathrm{MgO}, \mathrm{CaO}, \mathrm{CaCl}_{2}$, and $\mathrm{HCl}$ (IISC Method) have been very effective fluoride removal also cost effect and simple to adopt this technology at village level.

\section{Acknowledgement}

As a part of a Department of Science and Technology, New Delhi, Government of India Water Technology Initiative Project, focusing on low cost defluoridation filters for rural use, $\mathrm{MgO}, \mathrm{CaO}$ and $\mathrm{CaCl}_{2}$ based filters have been adapted and tested, both in the laboratory and in the field for the last three years. 


\section{References}

[1] Ayoob, S., Gupta, A. K. "Fluoride in Drinking Water: A Review on the Status and Stress Effects", Critical Reviews in Environmental Science and Technology, 36(6), pp. 433-487, 2006. https://doi.org/10.1080/10643380600678112

[2] Bhatnagar, A., Kumar, E., Sillanpää, M. "Fluoride removal from water by adsorption - a review", Chemical Engineering Journal, 171(3), pp. 811-840, 2011. http://doi.org/10.1016/j.cej.2011.05.028

[3] Susheela, A. K. "A treatise on fluorosis", 3rd ed., Fluorosis Research and Rural Development Foundation, Delhi, 2007.

[4] Bureau of Indian Standards (BIS) "Indian Standard Drinking Water - Specification (Second Revision)", IS 10500, BIS, New Delhi, India, 2012. [online] Available at: http://cgwb.gov.in/Documents/ WQ-Standards.pdf [Accessed: 31 January 2018]

[5] Ojekunle, O. Z., Ojekunle, O. V., Adeyemi, A. A., Taiwo, A. G., Sangowusi, O. R., Taiwo, A. M., Adekitan, A. A. "Evaluation of surface water quality indices and ecological risk assessment for heavy metals in scrap yard neighbourhood", SpringerPlus, 5(560), pp. 1-16, 2016.

https://doi.org/10.1186/s40064-016-2158-9

[6] Bureau of Indian Standards (BIS) "Draft Indian Standard-Drinking Water - Specification (Second Revision of IS 10500), IS 10500, BIS, New Delhi, India, 2009. [online] Available at: http://bis.org. in/sf/fad/FAD25(2047)C.pdf [Accessed: 31 January 2018]

[7] Fawell, J., Bailey, K., Chilton, J., Dahi, E., Fewtrell, L., Magara, Y. "Fluoride in Drinking-water", WHO, IWA Publishing, London, United Kingdom, 2006. [online] Available at: http://www.who.int/ water_sanitation_health/publications/fluoride_drinking_water_ full.pdf [Accessed: 31 January 2018]

[8] Brindha, K., Elango, L. "Fluoride in Groundwater: Causes, Implications and Mitigation Measures", In: Fluoride Properties, Applications and Environmental Management, 1st ed., Nova Publication, 2011, pp. 111-136. [online] Available at: https:// www.researchgate.net/publication/220000345_Fluoride_in_ Groundwater_Causes_Implications_and_Mitigation_Measures. [Accessed: 31 January 2018]

[9] Nagendra Rao, C. R. "Fluoride and Environment - A Review", In: Proceedings of the Third International Conference on Environment and Health, Chennai, India, 2003, pp. 386-399. [online] Available at: http://www.yorku.ca/bunchmj/ICEH/ proceedings/Rao_N_ICEH_papers_386to399.pdf [Accessed: 31 January 2018]

[10] Hussain, J., Sharma, K. C., Hussain, I. "Fluoride in Drinking Water in Rajasthan and Its Ill Effects on Human Health", Journal of Tissue Research, 4(2), pp. 263-273, 2004. [online] Available at: http://www.tcrjournals.com/uploads/9621216._Hussain.pdf [Accessed: 31 January 2018]

[11] Reimann, C., Bjorvatn, K., Frengstad, B., Melaku, Z., TekleHaimanot, R., Siewers, U. "Drinking water quality in the Ethiopian section of the East African Rift Valley I-data and health aspects", Science of the Total Environment, 311(1-3), pp. 65-80, 2003. https://doi.org/10.1016/S0048-9697(03)00137-2
[12] Hurtado, R., Gardea-Torresdey, J., Tiemann, K. J. "Fluoride Occurrence in Tap Water at "Los Altos de Jalisco" in the Central Mexico Region, In: Proceedings of the 2000 Conference on Hazardous Waste Research, Denver, Colorado, USA, 2000, pp. 211-219. [online] Available at: https://www.engg. ksu.edu/HSRC/00Proceed/gardea_torredeyl.pdf [Accessed: 31 January 2018]

[13] Mohapatra, D., Mishra, D., Mishra, S. P., Chaudhury, G. R., Das, R. P. "Use of oxide minerals to abate fluoride from water", Journal of Colloid and Interface Science, 275(2), pp. 355-359, 2004. https://doi.org/10.1016/j.jcis.2004.02.051

[14] Susheela, A. K. "The Harmful Effects of Fluoride Pollution in India", A United Nation Sustainable Development Journal, 9(3), pp. 215-218, 1985. https://doi.org/10.1111/j.1477-8947.1985.tb01061.x

[15] Sharma, S. K. "Toxicity of Fluoride in Parts of Indian Subsurface Water", pp. 99-104, 2013. [online] Available at: http://aguas. igme.es/igme/publica/con_recu_acuiferos/009.pdf [Accessed: 31 January 2018]

[16] Indu, R., Krishnan, S., Shah, T. "Impacts of Groundwater Contamination with Fluoride and Arsenic: Affliction Severity, Medical Cost and Wage Loss in Some Villages of India", International Journal of Rural Management, 3(1), pp. 69-93, 2007. https://doi.org/10.1177/097300520700300104

[17] Planning Commission, Government of India "Rajasthan Development Report", [pdf] Academic Foundation, New Delhi, India, pp. 276-277, 2006. Available at: http://planningcommission.gov.in/plans/stateplan/sdr/sdr_rajasthan.pdf [Accessed: 31 January 2018]

[18] Ranawat, P. S. "Nature of Fluorspar mineralization at ChowkriChhapoli, Sikar-Jhunjhunu Districts, Rajasthan", Journal of the Geological Society of India, 20(1), pp. 25-30, 1979. [online] Available at: http://www.geosocindia.org/index.php/jgsi/article/ view/64428 [Accessed: 31 January 2018]

[19] Shyam, R., Kalwania, G. S. "Ground water chemistry: A case study of eastern part of Sikar city (Rajasthan), India", International Journal of Applied Engineering Research, 2(2), pp. 367-378, 2011. [online] Available at: http://www.ipublishing.co.in/jarvol1no12010/ voltwo/EIJAER2241.pdf [Accessed: 31 January 2018]

[20] Chaudhary, V., Sharma, M., Yadav, B. S. "Assessment of water fluoride toxicity levels in Northwest Rajasthan, India", Fluoride, 41(3), pp. 212-215, 2008. [online] Available at: http://www.fluorideresearch.org/413/files/FJ2008_v41_n3_p212-215.pdf [Accessed: 31 January 2018]

[21] Larsen, M. J., Pearce, E. I., Ravnholt, G. "The effectiveness of bone char in the defluoridation of water in relation to its crystallinity, carbon content and dissolution pattern", Archives of Oral Biology, 39(9), pp. 807-816, 1994. [online] Available at: https://www.ncbi. nlm.nih.gov/pubmed/7802616 [Accessed: 31 January 2018]

[22] Mwaniki, D. L., Courtney, J. M., Gaylor, J. D. "Endemic fluorosis: An analysis of needs and possibilities based on case studies in Kenya", Social Science \& Medicine, 39(6), pp. 807-813, 1994. https://doi.org/10.1016/0277-9536(94)90042-6 
[23] Christoffersen, J., Christoffersen, M. R., Larsen, R., Møller, I. J. "Regeneration by surface-coating of bone char used for defluoridation of water", Water Research, 25(2), pp. 227-229, 1991. https://doi.org/10.1016/0043-1354(91)90033-M

[24] Larsen, M. J., Pearce, E. I. F. "Partial Defluoridation of Drinking Water Using Fluorapatite Precipitation", Caries Research, 26(1), pp. 22-28, 1992. https://doi.org/10.1159/000261421

[25] Okello, P. K. "Investigating contact precipitation as a viable water defluoridation technique", MSc Thesis, Egerton University, 2012. [online] Available at: http://ir-library.egerton.ac.ke/jspui/ bitstream/123456789/305/1/Investigating $\% 20$ Contact $\% 20$ Precipitation $\% 20 \% 20 \mathrm{As} \% 20 \mathrm{a} \% 20$ Viable $\% 20$ Water $\% 20$ Defluoridation\%20Technique.pdf [Accessed: 31 January 2018]

[26] Dahi, E. "Development of the Contact Precipitation Method for Appropriate Defluoridation of Water", In: Proceedings of the 2nd International Workshop on Fluorosis Prevention and Defluoridation of Water, Nazreth, Ethiopia, 1997, pp. 128-137. [online] Available at: http://orbit.dtu.dk/en/publications/development-of-the-contact-precipitation-method-for-appropriate-defluoridation-of-water(0058630e-a292-4922-a3ff-5d7970158b7f).html [Accessed: 31 January 2018]

[27] Nawlakhe, W. G, Kulkarni, D. N, Pathak, B. N, Bulusu, K. R. "Defluoridation of water by Nalgonda technique", Indian Journal of Environmental Health, 17(1), pp. 26-65, 1975.

[28] Dahi, E., Mtalo, F., Njau, B., Bregnhj, H. "Defluoridation using the Nalgonda Technique in Tanzania", In: Reaching the Unreached: Challenges for the 21st Century: Proceedings of 22nd WEDC Conference, New Delhi, India, 1996, pp. 267-269. [online] Available at: https://wedc-knowledge.lboro.ac.uk/resources/conference/22/ Dahi.pdf [Accessed: 31 January 2018]

[29] Suneetha, N., Rupa, K. P., Sabitha, V., Kumar, K. K., Mohanty, S., Kanagasabapathy, A. S., Rao, P. "Defluoridation of water by a onestep modification of the Nalgonda technique", Annals of Tropical Medicine and Public Health, 1(2), pp. 56-58, 2008. https://doi.org/10.4103/1755-6783.50685

[30] Stewart, T. "Removal of Fluoride from Drinking Water: Analysis of Alumina based Sorption", Term Paper, FS, Institute of Biogeochemistry and Pollutant Dynamics, Department Environmental Science, ETH, Zürich, 3, pp. 22-24, 2009.

[31] Karthikeyan, G., Apparao, B. V., Meenakshi, S. "Defluoridation Properties of Activated Alumina", In: Proceedings of the 2nd International Workshop on Fluorosis Prevention and Defluoridation of Water, Nazreth, Ethiopia, 1997, pp. 78-82. [online] Available at: http://www.de-fluoride.net/2ndproceedings/78-82.pdf [Accessed: 31 January 2018]

[32] Leyva-Ramos, R., Medellin-Castillo, N. A., Jacobo-Azuara, A., Mendoza-Barron, J., Landin-Rodriguez, L. E., Martínez-Rosales, J. M., Aragon-Piña, A. "Fluoride removal from water solution by adsorption on activated alumina prepared from pseudo-boehmite", Journal of Environmental and Management, 18(5), pp. 301-309, 2008. [online] Available at: https://www.researchgate.net/publication/242302089_Fluoride_removal_from_water_solution by_adsorption_on_activated_alumina_prepared_from_pseudo-boehmite [Accessed: 31 January 2018]
[33] Venkobachar, C., Iyengar, L., Mudgal, A. K. "Household Defluoridation of Drinking Water Using Activated Alumina", In: Proceedings of the 2nd International Workshop on Fluorosis Prevention and Defluoridation of Water, Nazreth, Ethiopia, 1997, pp. 138-145. [online] Available at: http://www.de-fluoride.net/2ndproceedings/138-145.pdf [Accessed: 31 January 2018]

[34] Daw, R. K. "Experiences with domestic defluoridation in India", In: People-centred Approaches to Water and Environmental Sanitation: Proceedings of the 30th WEDC International Conference, Vientiane, Lao People's Democratic Republic, 2004, pp. 467-473. [online] Available at: https://wedc-knowledge.lboro.ac.uk/resources/conference/30/Daw.pdf [Accessed: 31 January 2018]

[35] Iyenger, L. "Defluoridation of water using Activated Alumina Technology: Studies carried out at IIT Kanpur", Indian Institute of Technology, A Report for UNICEF, New Delhi, India, pp. 1-9, 2005. [online] Available at: https://pdfs.semanticscholar.org/0406/4a7b040a8af7f0e600f2ece3a61403aa3aa7.pdf [Accessed: 31 January 2018]

[36] Chauhan, V. S., Dwivedi, P. K., Iyengar, L. "Investigations on activated alumina based domestic defluoridation units", Journal of Hazardous Materials, 139(1), pp. 103-107, 2007.

https://doi.org/10.1016/j.jhazmat.2006.06.014

[37] Vaish, A. K., Vaish, P. "A Case Study of Fluorosis Mitigation in Dungarpur District, Rajasthan, India", In: Proceedings of the 3rd International Workshop on Fluorosis Prevention and Defluoridation of Water, Chiang Mai, Thailand, 2000, pp. 97-104. [online] Available at: http://www.de-fluoride.net/3rdproceedings/97-104.pdf [Accessed: 31 January 2018]

[38] Draft Specifications for Domestic De-fluoridation Filter Unit and Activated Alumina for Defluoridation, UNICEF, Booklet, pp. 1-7, 2013. [online] Available at: http://www.unicefiec.org/document/ draft-specifications-for-domestic-household-defluoridation-filter-unit-booklet-english [Accessed: 31 January 2018]

[39] Dzung, N. V., Phong, H. H., Long, N. N., Qang, N. T., Waldemar, P. "Domestic Defluoridation of Water Using Locally Produced Activated Alumina", In: Proceedings of the 4th International Workshop on Fluorosis Prevention and Defluoridation of Water, Colombo, Sri Lanka, 2004, pp. 75-80. [online] Available at: http:// www.de-fluoride.net/4thproceedings/75-80. pdf [Accessed: 31 January 2018]

[40] Padmasiri, J. P. "Low Cost Domestic Defluoridation", In: Proceedings of the 2nd International Workshop on Fluorosis Prevention and Defluoridation of Water, Nazreth, Ethiopia, 1997, pp. 146-150. [online] Available at: http://de-fluoride.net/2ndproceedings/146-150.pdf [Accessed: 31 January 2018]

[41] Wang, Y., Reardon, E. J. "Activation and regeneration of a soil sorbent for defluoridation of drinking water", Applied Geochemistry, 16(5), pp. 531-539, 2001. https://doi.org/10.1016/S0883-2927(00)00050-0

[42] Jinadasa, K. B. P. N., Weerasooriya, S. W. R., Dissanayake, C. B. "A rapid method for the defluoridation of fluoride-rich drinking waters at village level", International Journal of Environmental Studies, 31(4), pp. 305-312, 1988. https://doi.org/10.1080/00207238908710435 
[43] Gupta, A., Amitabh, V., Kumari, B., Mishra, B. "Defluoridation Capability of Jharkhand Raw Bentonite without Transferring Neurotoxin Aluminium by Potash Alum of Nalgonda Technique", IOSR Journal of Applied Chemistry, 7(3), pp. 1-10, 2014.

[44] Kvalheim, A., Bjorvatn, K., Bårdsen, A., Tekle-Haimanot, R. "Significance of Elevation on Fluoride Binding Capacity of Ethiopian Soils", In: $2^{\text {nd }}$ International Workshop on Fluorosis Prevention and Defluoridation of Water, Nazreth, Ethiopia, 1997, pp. 106-109. [online] Available at: http://www.de-fluoride.net/2ndproceedings/106-109.pdf [Accessed: 31 January 2018]

[45] Chidambaram, S., Manikandan, S., Ramanathan, A. L., Prasanna, M. V., Thivya, C., Karmegam, U., Thilagavathi, R., Rajkumar, K. "A study on the defluoridation in water by using natural soil", Applied Water Science, 3(4), pp. 741-751, 2013. https://doi.org/10.1007/s13201-013-0122-1

[46] Coetzee, P. P., Coetzee, L. L., Puka, R., Mubenga, S. "Characterisation of selected South African clays for defluoridation of natural waters", Water SA, 29(3), pp. 331-338, 2003. https://doi.org/10.4314/wsa.v29i3.4935

[47] Jayantha, K. S., Ranjana, G. R., Sheela, H. R., Ritu, M., Shivananni, Y. S. "Defluoridation studies using laterite material", Journal of Environmental Science and Engineering, 46(4), pp. 282-288, 2004. [online] Available at: https://europepmc.org/abstract/ med/16649627 [Accessed: 31 January 2018]

[48] Kamble, S. P., Dixit, P., Rayalu, S. S., Labhsetwar, N. K. "Defluoridation of drinking water using chemically modified bentonite clay", Desalination, 249(2), pp. 687-693, 2009. https://doi.org/10.1016/j.desal.2009.01.031

[49] Puka, L. R. "Fluoride adsorption modelling and the characterization of clays for defluoridation of natural waters", MSc Thesis, University of Johannesburg, South Africa, 2008. [online] Available at: http://hdl.handle.net/10210/413 [Accessed: 31 January 2018]

[50] Yadav, R. N., Yadav, R., Dagar, N. K., Gupta, P., Singh, O. P., Chandrawat, M. P. S. "Removal of Fluoride in Drinking Water by Green Chemical Approach", Journal of Current Chemical and Pharmaceutical Sciences, 2(1), pp. 69-75, 2012. [online] Available at: http://www.tsijournals.com/articles/removal-of-fluoride-in-drinking-water-by-greenchemical-approach.pdf [Accessed: 31 January 2018]

[51] Schneiter, R. W., Middlebrooks, E. J. "Arsenic and fluoride removal from groundwater by reverse osmosis", Environment International, 9(4), pp. 289-291, 1983. https://doi.org/10.1016/0160-4120(83)90087-9

[52] Richards, L. A., Richards, B. S., Rossiter, H. M. A., Schäfer, A. I. "Impact of speciation on fluoride, arsenic and magnesium retention by nanofiltration / reverse osmosis in remote Australian communities", Desalination, 248(1-3), pp. 177-183, 2009. https://doi.org/10.1016/j.desal.2008.05.054

[53] Dolar, D., Košutić, K., Vučić, B. "RO / NF treatment of wastewater from fertilizer factory-removal of fluoride and phosphate", Desalination, 265(1-3), pp. 237-241, 2011. https://doi.org/10.1016/j.desal.2010.07.057
[54] Schoeman, J. J., Steyn, A., Scurr, P. J. "Treatment using reverse osmosis of an effluent from stainless steel manufacture", Water Research, 30(9), pp. 1979-1984, 1996. [online] Available at: http://citeseerx. ist.psu.edu/viewdoc/download?doi=10.1.1.569.6572\&rep=rep1\&type=pdf [Accessed: 31 January 2018]

[55] Min, B. R., Gill, A. L., Gill, W. N. "A note on fluoride removal by reverse osmosis", Desalination, 49(1), pp. 89-93, 1984. https://doi.org/10.1016/0011-9164(84)80013-2

[56] Babu, C. A., Sujish, D., Murugappa, M. S., Mohanakrishnan, G., Kalyanasundaram, P., Raj, B. "A comprehensive treatment method for defluoridation of drinking water", Indian Journal of Chemical Technology, 18(4), pp. 314-318, 2011. [online] Available at: http://nopr.niscair.res.in/bitstream/123456789/12663/1/IJCT\%20 18\%284\%29\%20314-318.pdf [Accessed: 31 January 2018]

[57] Lahnid, S., Tahaikt, M., Elaroui, K., Idrissi, I., Hafsi, M., Laaziz, I., Amor, Z., Tiyal, F., Elmidaoui, A. "Economic evaluation of fluoride removal by electrodialysis", Desalination, 230(13), pp. 213-219, 2008. https://doi.org/10.1016/j.desal.2007.11.027

[58] Elazhar, F., Tahaikt, M., Zouahri, A., Taky, M., Hafsi, M., Elmidaoui, A. "Defluoridation of Moroccan Groundwater by Nanofiltration and Electrodialysis: Performances and Cost Comparison", World Applied Science Journal, 22(6), pp. 844-850, 2013. https://doi.org/10.5829/idosi.wasj.2013.22.06.268

[59] Tahaikt, M., Achary, I., Menkouchi Sahli, M. A., Amor, Z., Taky, M., Alami, A., Boughriba, A., Hafsi, M., Elmidaoui, A. "Defluoridation of Moroccan groundwater by electrodialysis: continuous operation", Desalination, 189(1-3), pp. 215-220, 2006. https://doi.org/10.1016/j.desal.2005.06.027

[60] Ali, M. B. S., Hamrouni, B., Dhahbi, M. "Electrodialytic Defluoridation of Brackish Water: Effect of Process Parameters and Water Characteristics", Clean Soil Air Water, 38(7), pp. 623629, 2010. https://doi.org/10.1002/clen.200900301

[61] Kabay, N., Arar, Ö., Samatya, S., Yüksel, Ü., Yüksel, M. "Separation of fluoride from aqueous solution by electrodialysis: Effect of process parameters and other ionic species", Journal of Hazardous Materials, 153(1-3), pp. 107-113, 2008. https://doi.org/10.1016/j.jhazmat.2007.08.024

[62] Amor, Z., Malki, S., Taky, M., Bariou, B., Mameri, N., Elmidaoui, A. "Optimization of fluoride removal from brackish water by electrodialysis", Desalination, 120(3), pp. 263-271, 1998. https://doi.org/10.1016/S0011-9164(98)00223-9

[63] Amor, Z., Bariou, B., Mameri, N., Taky, M., Nicolas, S., Elmidaoui, A. "Fluoride removal from brackish water by electrodialysis", Desalination, 133(3), pp. 215-223. 2001. https://doi.org/10.1016/S0011-9164(01)00102-3

[64] Adhikary, S. K., Tipnis, U. K., Harkare, W. P., Govindan, K. P. "Defluoridation during desalination of brackish water by electrodialysis", Desalination, 71(3), pp. 301-312, 1989. https://doi.org/10.1016/0011-9164(89)85031-3 
[65] Zeni, M., Riveros, R., Melo, K., Primieri, R., Lorenzini, S. "Study on fluoride reduction in artesian well-water from electrodialysis process", Desalination, 185(1-3), pp. 241-244, 2005. https://doi.org/10.1016/j.desal.2005.03.080

[66] Menkouchi Sahli, M. A., Annouar, S., Tahaikt, M., Mountadar, M., Soufiane, A., Elmidaoui, A. "Fluoride removal for underground brackish water by adsorption on the natural chitosan and by electrodialysis", Desalination, 212(1-3), pp. 37-45, 2007. https://doi.org/10.1016/j.desal.2006.09.018

[67] Banasiak, L. J., Schäfer, A. I. "Removal of boron, fluoride and nitrate by electrodialysis in the presence of organic matter", Journal of Membrane Science, 334(1-2), pp. 101-109, 2009. http://doi.org/10.1016/j.memsci.2009.02.020

[68] Maheshwari, R., Garg, A., Katyal, P., Kumar, M., Rani, B., Sharma, M., Prasad, M., Gaur, M. "Mitigating Fluoride Toxicity Occurring in Groundwater of Nagaur City (Rajasthan), Employing Various Bioadsorbents", Bulletin of Environment, Pharmacology and Life Sciences, 1(7), pp. 50-53, 2012. [online] Available at: http://www. bepls.com/june2012/11.pdf [Accessed: 31 January 2018]

[69] Mondal, N. K., Bhaumik, R., Baur, T., Das, B., Roy, P., Datta, J. K. "Studies on Defluoridation of Water by Tea Ash: An Unconventional Biosorbent", Chemical Science Transactions, 1(2), pp. 239-256, 2012. https://doi.org/10.7598/cst2012.134

[70] Ardekani, M. M. M., Kalantary, R. R., Jorfi, S., Nurisepehr, M. "Comparison the Efficiency of Bagas, Modified Bagas and Chitosan for Fluoride Removal from Water by Adsorption", Journal of Environmental Treatment Techniques, 1(1), pp. 1-7, 2013. [online] Available at: http://www.jett.dormaj.com/docs/Volume1/Issue1/ jett-p1_1-1.pdf [Accessed: 31 January 2018]

[71] Liang, P., Zhang, Y., Wang, D., Xu, Y., Luo, L. "Preparation of mixed rare earths modified chitosan for fluoride adsorption", Journal of Rare Earths, 31(8), pp. 817-822, 2013. https://doi.org/10.1016/S1002-0721(12)60364-0

[72] Vardhan, C. M. V., Karthikeyan, J. "Removal of Fluoride from Water Using Low-Cost Materials", International Water Technology Journal, 1(2), pp. 120-131, 2011. [online] Available at: http://iwtj.info/wp-content/uploads/2011/12/v1-n2-p3.pdf [Accessed: 31st January 2018]

[73] Veeraputhiran, V., Alagumuthu, G. "Treatment of High Fluoride Drinking Water Using Bioadsorbent", Research Journal of Chemical Sciences, 1(4), pp. 49-54, 2011. [online] Available at: https://www. researchgate.net/profile/V_Veeraputhiran/publication/215993884 Treatment_of_High_Fluoride_Drinking_Water_Using Bioadsorbent/links/54c9ca390cf2807dcc27e810/Treatment-ofHigh-Fluoride-Drinking-Water-Using-Bioadsorbent.pdf [Accessed: 31 January 2018]

[74] Oke, K., Neumann, S., Adams, B. "Selective Fluoride Removal", Water Today, 1, pp. 76-80, 2011. [online] Available at: https:// pdfs.semanticscholar.org/90ce/e3a9f697c59045c11c2a24626accd8806a7f.pdf [Accessed: 31st January 2018]

[75] Ho, L. N., Ishihara, T., Ueshima, S., Nishiguchi, H., Takita, Y. "Removal of fluoride from water through ion exchange by mesoporous Ti oxohydroxide", Journal of Colloid and Interface Science, 272(2), pp. 399-403, 2004.

https://doi.org/10.1016/j.jcis.2003.08.051
[76] Castel, C., Schweizer, M., Simonnot, M. O., Sardin, M. "Selective removal of fluoride ions by a two-way ion- exchange cyclic process", Chemical Engineering Science, 55(17), pp. 3341-3352, 2000. https://doi.org/10.1016/S0009-2509(00)00009-9

[77] Kumar, S., Chauhan, G. S., Gupta, R., Kant, S., Sharma, R. K. "Designing a cost-effective and dual-functional muslin-based anion exchanger for defluoridation", Desalination and Water Treatment, 52(34-36), pp. 6792-6801, 2014. https://doi.org/10.1080/19443994.2013.827790

[78] Ruixia, L., Jinlong, G., Hongxiao, T. "Adsorption of Fluoride, Phosphate, and Arsenate Ions on a New Type of Ion Exchange Fiber", Journal of Colloid and Interface Science, 248(2), pp. 268-274, 2002. https://doi.org/10.1006/jcis.2002.8260

[79] Singh, G., Kumar, B., Sen, P. K., Majumdar, J. "Removal of Fluoride from Spent Pot Liner Leachate Using Ion Exchange", Water Environment Research, 71(1), pp. 36-42, 1999. [online] Available at: https://www.jstor.org/stable/25045172?seq=1\#page _ scan_tab_contents [Accessed: 31st January 2018]

[80] Rao, S. M., Mamatha, P. "Water quality in sustainable water management", Current Science, 87(7), pp. 942-947, 2004. [online] Available at: https://www.jstor.org/stable/24109398 [Accessed: 31st January 2018]

[81] Pemmaraju, M. "A Magnesia Based Sustainable Method For De-Fluoridation of Contaminated Groundwater", $\mathrm{PhD}$ Dissertation, Indian Institute of Science (IISc), 2008. [online] Available at: http://etd.ncsi.iisc.ernet.in/handle/2005/915 [Accessed: 31st January 2018]

[82] Pemmaraju, M., Rao, S. M. "A sustainable option for de-fluoridation of water using magnesium oxide", In: Proceedings of International Conference on Energy Environment and Disasters (INCEED), Charlotte, USA, 2005, pp. 24-30.

[83] Pemmaraju, M., Rao, S. M. "De-fluoridation of groundwater using magnesium oxide", The Environmentalist, 31(1), pp. 39-53, 2011. https://doi.org/10.1007/s10669-010-9299-0

[84] Rao, S. M., Venkataram Reddy, B. V., Pemmaraju, M. "Process for the Treatment of Fluoride Contaminated Water and a Domestic De-fluoridation Unit", Indian Institute of Science (IISc), 2009.

[85] Rao, S. M. "Application Notes on IISc method of defluoridation", Indian Institute of Science (IISc), pp. 1-11, 2015. [online] Available at: http://civil.iisc.ernet.in/ msrao/files/applicationIIScmethod. pdf [Accessed: 31 January 2018]

[86] Margandan, K., Agrawal, R., Achriya,R., Qanungo, K. "Studies on Cement Stabilsed Mud Blocks for Sludge Disposal from $\mathrm{MgO}, \mathrm{CaCl}_{2}, \mathrm{CaO}$ and $\mathrm{HCl}$ Based Defluoridation Filters in Rural Rajasthan", International Journal of ChemTech Research, 8(8), pp. 357-362, 2015. [online] Available at: http://sphinxsai.com/2015/ ch_vol8_no8/2/(357-362)V8N8CT.pdf [Accessed: 31 January 2018]

[87] Margandan, K., Qanungo, K. "Optimization of $\mathrm{CaO}$ Dosage in a $\mathrm{MgO}-\mathrm{CaCl}_{2}-\mathrm{CaO}-\mathrm{HCl}$ Based Defluoridation Technique", International Journal of Innovative Research in Technology, Science \& Engineering (IJIRTSE), 2(3), pp. 28-34, 2016. [online] Available at: http://www.ioirp.com/Doc/IJIRTSE/V2_ I3/6ICISET54.pdf [Accessed: 31 January 2018] 
[88] Meenakshi, Maheshwari, R. C. "Fluoride in drinking water and its removal", Journal of Hazardous Materials, 137(1), pp. 456-463, 2006.

https://doi.org/10.1016/j.jhazmat.2006.02.024

[89] Jha, S. K., Singh, R. K., Damodaran, T., Mishra, V. K., Sharma, D. K., Rai, D. "Fluoride in Groundwater: Toxicological Exposure and Remedies", Journal of Toxicology and Environmental Health, Part B, 16(1), pp. 52-66, 2013. http://doi.org/10.1080/10937404.2013.769420

[90] Choubisa, S. L., Choubisa, L., Choubisa, D. K. "Endemic fluorosis in Rajasthan", Indian Journal of Environmental Health, 43(4), pp. 177-189, 2001. [online] Available at: http://europepmc.org/ abstract/med/12395525 [Accessed: 31st January 2018]

[91] Chahal, R. P. S., Chahal, P. P. K. "Effect of Fluoride Content of Drinking Water on Dental Fluorosis in the Punjab State", Journal of Advanced Medical and Dental Sciences Research, 4(3), pp. 4-6, 2016. [online] Available at: http://jamdsr.com/uploadfiles/2. FLUORIDECONTENTOFDRINKINGWATERONDENTAL FLUOROSIS.20160510070036.pdf [Accessed: 31 January 2018]

[92] Sarvaiya, B. U., Bhayya, D., Arora, R., Mehta, D. N. "Prevalence of dental fluorosis in relation with different fluoride levels in drinking water among school going children in Sarada tehsil of Udaipur district, Rajasthan", Journal of Indian Society of Pedodontics and Preventive Dentistry, 30(4), pp. 317-322, 2012. https://doi.org/10.4103/0970-4388.108929

[93] Susheela, A. K. "Epidemiological studies of health risks from drinking water naturally contaminated with fluoride", In: Assessing and Managing Health Risks from Drinking Water Contamination: Approaches and Applications", IAHS Press, Wallingford, Oxfordshire, UK, 1995, pp. 123-134. [online] Available at: http://hydrologie.org/redbooks/a233/iahs_233_0123. pdf [Accessed: 31 January 2018]

[94] Brudevold, F., Soremark, R. "Chemistry of the mineral phase of enamel", In: Miles, A. E. W. (ed.) Structural and Chemical Organisation of Teeth", Academics Press, New York, USA, 2, 1967, pp. 247-277.
[95] Si, Y., Zhang, B. "Epidemiology Study of Dental Fluorosis in China", In: 4th International Workshop on Fluorosis Prevention and Defluoridation of Water, Colombo, Sri Lanka, 2004, pp. 9-18. [online] Available at: http://www.de-fluoride.net/4thproceedings/9-18.pdf [Accessed: 31 January 2018]

[96] Shivashankara, A. R., Shivaraja Shankara, Y. M., Rao, S. H., Bhat, P. G. "A Clinical and Biochemical Study of Chronic Fluoride Toxicity in Children of Kheru Thanda of Gulbarga District, Karnataka, India", Fluoride, 33(2), pp. 66-73, 2000. [online] Available at: https://pdfs.semanticscholar.org/c6bb/36b22778d58f342e0571e239af3d2b8c3f94.pdf [Accessed: 31 January 2018]

[97] Teotia, S. P. S., Teotia, M., Singh, K. P. "Highlights of Forty Years of Research on Endemic Skeletal Fluorosis in India", In: 4th International Workshop on Fluorosis Prevention and Defluoridation of Water, Colombo, Sri Lanka, 2004, pp. 107-125. [online] Available at: http://www.de-fluoride.net/4thproceedings/107-125.pdf [Accessed: 31 January 2018]

[98] Tsutsui, T., Suzuki, N., Ohmori, M., Maizumi, H. "Cytotoxicity, chromosome aberration and unscheduled DNA synthesis in cultural human diploid fibroblasts induced by sodium fluoride", Mutation Research Letters, 139(4), pp. 193-198, 1984. https://doi.org/10.1016/0165-7992(84)90127-1

[99] Wang, A. G., Xia, T., Chu, Q. L., Zhang, M., Liu, F., Chen, X. M., Yang, K. D. "Effects of fluoride on lipid peroxidation, DNA damage and apoptosis in human embryo hepatocytes", Biomedical and Environment Sciences, 17(2), pp. 217-222, 2004. [online] Available at: https://pdfs.semanticscholar. org/7f22/83216139e52f719843e1112d214b79e144ce.pdf [Accessed: 31 January 2018] 